\title{
A Look at American Legal Practice Through a Perspective of Jewish Law, Ethics, and Tradition: A Conceptual Overview
}

Samuel J. Levine

Touro Law Center, slevine@tourolaw.edu

Follow this and additional works at: https://digitalcommons.tourolaw.edu/scholarlyworks

Part of the Legal Ethics and Professional Responsibility Commons, and the Other Law Commons

\section{Recommended Citation}

20 Notre Dame J. L. Ethics \& Pub. Pol'y 12 (2006)

This Article is brought to you for free and open access by the Faculty Scholarship at Digital Commons @ Touro Law Center. It has been accepted for inclusion in Scholarly Works by an authorized administrator of Digital Commons @ Touro Law Center. For more information, please contact Iross@tourolaw.edu. 


\title{
ARTICLES
}

\section{A LOOK AT AMERICAN LEGAL PRACTICE THROUGH A PERSPECTIVE OF JEWISH LAW, ETHICS, AND TRADITION: A CONCEPTUAL OVERVIEW}

\author{
SAMUel J. Levine*
}

\section{INTRODUCTION}

A discussion of American legal practice through a perspective of Jewish law, ethics, and tradition may be considered under at least two distinct but interrelated approaches. A historical approach might look to attitudes toward lawyers found in sources relating to courts that have functioned under the Jewish legal system. However, as Part I of this Essay briefly explains, because Jewish courts classically operated under an inquisitorial system of justice, relatively few primary sources of Jewish law include material addressing the role of lawyers. Accordingly, references to lawyers in Jewish law and tradition may remain of little relevance to the practice of law in the contemporary United States, as any normative conclusions derived from these sources likely depend upon underlying assumptions inapplicable to the American adversary legal system.

Thus, as Part II of the Essay suggests, an alternative approach might instead focus more generally upon areas of Jewish law and ethics that, although perhaps not always directly related to the substance of legal practice, may in fact offer a

* Associate Professor of Law, Pepperdine University School of Law. L.L.M., Columbia University; J.D., Fordham University; Rabbinical Ordination, Yeshiva University; B.A., Yeshiva University.

An earlier version of this Article was presented as part of a program at the 2006 Annual Meeting of the Association of American Law Schools (A.A.L.S.), in Washington, D.C. The program, "Professional Responsibility and the Religious Traditions," was co-sponsored by the A.A.L.S. Section on Professional Responsibility and the A.A.L.S. Section on Law and Religion, and was organized by Marie Failinger. The author would like to thank Russ Pearce and Nancy Rapoport for helpful comments, and Fraida Liba, Yehudah, Aryeh, and Rachel for continued encouragement. 
more accurate indication of the attitudes of Jewish tradition toward the work of American lawyers. Toward that end, Part II presents a three-tiered conceptual framework suitable for an analysis of the implications for Jewish law and ethics of a broad range of human activities, including various aspects of the practice of law. Finally, branching out from Jewish tradition, the Essay concludes with a broader reference to the effectiveness of the religious lawyering movement in providing a means for improving exploration of and attitudes toward the work and ethics of lawyers.

\section{Absence of the Lawyer in the Traditional Jewish LEGAL SYSTEM}

As a historical matter, primary sources of Jewish law and tradition, which include extensive material relating to nearly every aspect of life and law, ${ }^{1}$ remain largely bereft of discussions relating to the role of lawyers. The absence of such information reflects the nature of the Jewish legal system, which classically functioned under an inquisitorial model of court proceedings, rather than employing the kind of adversarial model central to the American legal system. ${ }^{2}$ Thus, in place of the expectation that lawyers will formulate, advocate, and challenge legal claims and strategies, the Jewish legal system relied upon the parties to state their claims and upon judges to insure fairness through active participation in all stages of the trial, including questioning parties and witnesses, before adjudicating the matter. ${ }^{3}$

Not surprisingly, therefore, the Talmud instructs against engaging in the conduct of orkhe ha-dayanim, apparently referencing behavior typical of lawyers who provide strategic assistance to their clients. ${ }^{4}$ Although on its face the Talmudic principle seems to suggest a negative impression of the work of lawyers, the admonition likely addresses judges, who had to take great care not to allow their inquisitorial role to border upon perceived or actual favoritism toward one of the parties. ${ }^{5}$ Similarly, to the

1. See, e.g., 1 Aryeh Kaplan, The Handbook of Jewish Thought 78 (1979) (noting "the multitude of laws governing even such mundane acts as eating, drinking, dressing and business ... ").

2. See, e.g., Michael J. Brovde, The Pursuit of Justice and Jewish Law: Halakhic Perspectives on the Legal Profession 11-12 (1996); Dov I. Frimer, The Role of the Lawyer in Jewish Law, 1 J. L. \& ReLigion 297, 297-301 (1983).

3. BROYDE, supra note 2, at 11-12; Frimer, supra note 2, at 297-301.

4. The Talmud, Aboth 1:8 (I. Epstein, ed. \& trans., Soncino Press 1935) [herinafter TALMUD, Aboth 1:8].

5. See Brovde, supra note 2, at 12-14; Basil F. Herring, Jewish Ethics and Halakhah for Our Time: Sources and Commentary 99, 117 n.1 (1984). 
extent that the Talmud's instruction to judges incorporates an implicit critique of the practices of lawyers, such criticism is arguably directed at either outright dishonesty or forms of advocacy intended to subvert the proper role of the judges. ${ }^{6}$ Although over time there has developed within courts of Jewish law a form of legal representation, the parameters of legal advocacy are likewise limited so as not to interfere with the traditional judicial function. ${ }^{7}$ Thus, in light of the systemic differences between the Jewish legal model and the American legal model, reliance on the historical record of lawyers within the Jewish legal system likely proves tenuous at best for the purposes of ascertaining attitudes in Jewish law and tradition toward the work of contemporary American lawyers. ${ }^{8}$

\section{A Conceptual Framework}

In the apparent absence of a direct analogue in Jewish legal tradition corresponding to the American practice of law, a more helpful mode of analysis might instead consider attitudes in Jew-

See also MaImonides, MishneH TORAH, Laws of Sanhedrin 21:11; Bachya BEN Asher, Commentary on the Torah 239 (Chaim Dov Chavel ed., 1991) (explicating Leviticus 23:2).

6. See Broyde, supra note 2, at 21-22. But see Mordecai Biser, Can an Observant Jew Practice Law? A Look at Some Halakhic Problems, 11 Jewish L. ANN. 101, 131-32 (1994) (arguing that those engaged in the conduct of orkhe hadayanim are "criticized not only for seeking to pervert the [Jewish legal] inquisitorial system by introducing elements of advocacy, but because engaging in legal legerdemain is itself regarded as unethical.").

7. See, e.g., BROYDE, supra note 2, at 19-23; Frimer, supra note 2, at 301-02; HeRring, supra note 5, at 116-17.

8. Notably, although the Jewish legal system relies upon an inquisitorial model rather than an adversarial model, Jewish tradition accepts the general proposition that, when conducted with pure motives, an adversarial process will prove valuable in achieving a proper resolution of a legal issue. See, e.g., TALMud, Avoth 5:20; TALmud BAvLI, Kiddushin 30b. Indeed, to some extent the Jewish legal system incorporates an adversarial dynamic, illustrated in one of the methods for composing a Jewish court of three judges. Specifically, each party first selects a judge to serve on the court, and together the two judges then select a third judge. Although judges are prohibited from favoring either party, the process is intended to insure that the position of each party will be fully and adequately presented and considered. See Broyde, supra note 2, at 13-14; Frimer, supra note 2, at 299.

Conversely, there have long existed discussions and debates among American legal scholars regarding the ethics and effectiveness of a system incorporating advocacy and adversary justice. For extensive consideration of these issues, see, for example, Monroe H. Freedman \& Abbe Smith, Understanding Lawyers' Ethics 13-43 (3d ed. 2004); STEPHEN Gillers, Regulation of LaWyers: Problems of Law and Ethics 315-31 (7th ed. 2005); Charles W. Wolfram, Modern Legal Ethics 563-92 (1986). 
ish law and ethics toward conduct typical of American lawyers. As scholars of Jewish law have emphasized, Jewish thought aims to elevate all realms of human endeavor through ethical conduct in every area of life. ${ }^{9}$ In the words of Rabbi Joseph Soloveitchik, " $[t]$ he true sanctuary is the sphere of our daily, mundane activities, for it is there that the realization of [Jewish law] takes place." ${ }^{10}$ Thus, an analysis of the work of lawyers through a perspective of Jewish tradition would require conceptual consideration of the ethics of specific aspects of legal practice, rather than viewing the practice of law as a parochial form of activity, subject only to its own unique rules of morality and consequently immune from others. ${ }^{11}$ Indeed, a number of American legal ethics scholars have similarly aimed to dispel the notion that the status of legal practice as a "profession" entitles lawyers to inherent claims of virtue and morality. Instead, these scholars have emphasized, the practice of law, like other areas of human endeavor, has the potential for virtue or for vice, depending on the manner in which it is performed. ${ }^{12}$

9. See, e.g., KAPLAN, supra note 1 , at 78 (stating that the commandments "penetrate every nook and cranny of a person's existence, hallowing even the lowliest acts and elevating them to a service to God. . . . sanctify every facet of life, and constantly remind one of [one's] responsibilities toward God."). See also Samuel J. Levine, The Broad Life of the Jewish Lawyer: Integrating Spirituality, Scholarship and Profession, 27 TEx. TECH L. REv. 1199 (1996) [hereinafter Levine, Broad Life]; Samuel J. Levine, Reflections on the Practice of Law as a Religious Calling, From a Perspective of Jewish Law and Ethics, 32 PePP. L. Rev. 411, 411-13 \& nn.1-10 (2005) [hereinafter Levine, Practice of Law as a Religious Calling].

10. Joseph B. Soloveitchik, Halakhic Man 94-95 (Lawrence Kaplan trans., 1983) (originally published in Hebrew as IsH HA-HALAKHAH, in 1 TALPIOT 3-4 (1944)); see also Chaim YaAkov Goldvicht, Arba'A MA'amrim B'AgGada 21-31 (1984); Bachya Ben Asher, Kad Ha-kemach, in Kisvei Rabbenu Bachya 350-54 (Chaim Dov Chavel ed., 1995).

11. On some level, then, a fitting response to the question of the attitude of Jewish law and tradition toward the practice of law might resemble Judge Easterbrook's response to the question of the law of property in cyberspace. See Frank H. Easterbrook, Cyberspace and the Law of the Horse, 1996 U. CHI. LeGal F. 207. Judge Easterbrook posited that "the best way to learn the law applicable to specialized endeavors is to study general rules." Id. at 207. Thus, he argued, in assessing the law of "Property in Cyberspace," the most effective approach would be to "[d] evelop a sound law of intellectual property, then apply it to computer networks." Id. at 208 (emphasis in original). See also Frank H. Easterbrook, Intellectual Property is Still Property, 13 Harv. J.L. \& Pub. Pol'y 108 (1990). Likewise, the most helpful approach to the question of legal practice in Jewish law and tradition might entail the identification of general laws regarding proper and ethical conduct, which are then applied to conduct involved in the practice of law.

12. See, e.g., Robert F. Cochran, Jr., Professionalism in the Postmodern Age: Its Death, Attempts at Resuscitation, and Alternate Sources of Virtue, 14 NOTRE DAME J.L. Ethics \& Pub. Pol'y 305 (2000); David Luban, Asking the Right Questions, 72 
Accordingly, an effective conceptual analogue in Jewish tradition for a consideration of American legal practice may be found in a broadly applicable three-tiered approach, one that is similarly helpful in an analysis of the decidedly mundane-and ostensibly unrelated-activity of eating. ${ }^{13}$ On one level, Jewish law includes technical legal precepts, in the form of both positive and negative commandments, regarding what food may ${ }^{14}$-and, at times, should ${ }^{15}$-be eaten, the way food should be prepared, ${ }^{16}$ and rituals surrounding a meal. ${ }^{17}$ More broadly, Jewish law and ethics address the manner in which individuals are instructed to use their resources, including, for example, their willingness to share their food with those who are needy. ${ }^{18}$ Finally, Jewish thought teaches the possibility of elevating the act of eating through the incorporation into a meal of otherwise incidental virtuous conduct, such as the study of Torah, through which participants may be considered, as it were, to be eating at the "table of God." 19 In turn, each of these categories may be applicable in an analytical framework considering the practice of law in terms of technical aspects of legal practice, broader aspects of legal

Temple L. Rev. 839 (1999); Russell G. Pearce, Law Day 2050: Post-Professionalism, Moral Leadership, and the Law-as-Business Paradigm, 27 Fla. ST. U. L. Rev. 9 (1999); Russell G. Pearce, The Professionalism Paradigm Shift: Why Discarding Professional Ideology Will Improve the Conduct and Reputation of the Bar, 70 N.Y.U. L. Rev. 1229 (1995) [hereinafter Pearce, The Professional Paradigm Shift]; Patrick J. Schiltz, On Being a Happy, Healthy, and Ethical Member of an Unhappy, Unhealthy, and Unethical Profession, 52 VAND. L. Rev. 871 (1999); Thomas L. Shaffer, Inaugural Howard Lichtenstein Lecture in Legal Ethics: Lawyer Professionalism as a Moral Argument, 26 Gonz. L. Rev. 393 (1990-1991); Thomas L. Shaffer, The Lost Law yer: Failing Ideals of the Legal Profession, 41 Loy. L. REv. 387 (1995) (book review); Richard Wasserstrom, Lawyers as Professionals: Some Moral Issues, 5 Hum. RTs. Q. 1 (1975). See also Samuel J. Levine, Faith in Legal Professionalism: Believers and Heretics, 61 Mo. L. Rev. 217 (2002) [hereinafter Levine, Faith in Legal Professionalism]; Samuel J. Levine, Professionalism Without Parochialism: Julius Henry Cohen, Rabbi Nachman of Breslov, and the Stories of Two Sons, 71 Fordham L. Rev. 1339 (2003); Samuel J. Levine, Rediscovering Julius Henry Cohen and the Origins of the Business/Profession Dichotomy: A Study in the Discourse of Early Twentieth Century Legal Professionalism, 47 Am. J. Legal Hist. 1 (2005).

13. See Hershel Schachter, Eretz Hatzevi: Be'urei Sugyot 286 (1992); see also Mordechai I. Willig, Am Mordechai on Tractate Berakhot 13-14 (1992); Bachya ben Asher, Shulchan Shel Arba, in Kisvei Rabbenu Bachya, supra note 10 , at 453 .

14. See, e.g., Maimonides, supra note 5, Laws of Forbidden Foods.

15. See, e.g., id., Laws of Chametz U'Matza, ch. 6.

16. See, e.g., id., Laws of Shechita.

17. See, e.g., id., Laws of Blessings.

18. See Schachter, supra note 13, at 286 (citing Talmud Bavli, Berachoth 55a; Maimonides, supra note 5, Laws of Yom Tov 6:18).

19. Talmud, Aboth 3:3. 
practice, including utilization of resources and abilities, and conduct incidental to the practice of law.

\section{A. Technical Aspects of Legal Practice}

Various technical aspects of the practice of law have potentially significant implications in the context of Jewish law and ethics, raising complex challenges to observance of a number of religious obligations. Concerns over these challenges have led some commentators to conclude that engaging in many areas of American legal practice may entail the express violation of Jewish law. ${ }^{20}$ Perhaps the most common issue of concern relates to the Talmudic directive prohibiting Jewish parties from litigating a dispute in a non-rabbinic court. ${ }^{21}$ By extension, a Jewish lawyer who represents a party in such litigation may violate a secondary prohibition against assisting others in committing a wrongdoing. ${ }^{22}$ Although both of these prohibitions are subject to a number of exceptions and qualifications, ${ }^{23}$ there remains a plausible argument that in adherence to these principles of Jewish law an attorney practicing in the United States may be obligated, at times, to decline clients, or potentially even to decline positions of employment. ${ }^{24}$

Similarly, a variety of business transactions have the potential of violating Biblical and rabbinic prohibitions, including, for

20. See Biser, supra note 6 passim; see also Israel Greisman, The Jewish Criminal Lawyer's Dilemma, 29 Fordham URB. L.J. 2413, 2419 (2002); Steven H. Resnicoff, A Jewish Look at Lawyering Ethics-A Preliminary Essay, 15 Touro L. REv. 73 (1998). But see Broyde, supra note 2 passim; Michael J. Broyde, On the Practice of Law According to Halacha, $20 \mathrm{~J}$. Halacha And Contemp. Soc'y 5 (1990); Michael J. Broyde, Practicing Criminal Law: A Jewish Law Analysis of Being a Prosecutor or Defense Attorney, 66 FordhaM L. Rev. 1141 (1998).

21. See Talmud Bavl, Gittin 88b; see also Brovde, supra note 2, at 41-48, 67-72; Biser, supra note 6, at 103-07; Simcha Krauss, Litigation in Secular Courts, 2 J. Halacha \& Contemp. Soc'y 35 (1982).

22. See Leviticus 19:14. See also Biser, supra note 6, at 108-12; Steven H. Resnicoff, Helping a Client Violate Jewish Law: A Jewish Lawyer's Dilemma, in JEwisH Law Association Studies X 191 (H.G. Sprecher ed., 2000). In fact, according to at least one commentator, the lawyer in such circumstances acts in violation of the primary prohibition against litigating in non-rabbinic courts. See Menasheh Klein, Mishne HalakHot 7:255, 3:214, cited in BroYde, supra note 2, at 50. For a response to this position, see BroYDE, supra note 2, at 50-52.

23. See BroYde, supra note 2, at 53-66; see also Biser, supra note 6, at 112; Resnicoff, supra note 20, at 88-92.

24. See Biser, supra note 6, at 112-16; Dov Bressler, Arbitration and the Courts in Jewish Law, 9 J. Halacha \& Contemp. Soc'y 105, 109-10 (1985); Resnicoff, supra note 20, at 83-96. But see BROYDE, supra note 2, at 53-66. 
example, charging or paying interest. ${ }^{25}$ Although methods have been formulated in Jewish law for structuring many transactions to comply with the restrictions on interest, ${ }^{26}$ the details of these methods are notoriously complex and the requirements often challenging in practice.$^{27}$ Accordingly, to the extent that a particular transaction fails adequately to comply with these requirements and thus violates prohibitions on interest, a lawyer who facilitates such a transaction may thereby be in breach of the secondary prohibition against enabling wrongdoing. ${ }^{28}$ In addition, because of the unique nature of the Biblical command regarding interest, the lawyer may concomitantly violate the primary substantive prohibition against active participation in a transaction involving interest. ${ }^{29}$

The work of a criminal lawyer represents yet another area in which commentators have considered potential conflicts between professional responsibilities of the practice of law and religious obligations under Jewish law. In analyzing the work of a prosecutor, many have looked to Talmudic sources critical of those who assisted the Romans in the apprehension of Jewish defendants. ${ }^{30}$ However, a number of scholars have found the Talmudic discussion inapplicable in the context of the American legal system, emphasizing fundamental distinctions between the conditions in contemporary American law and society and those existent in the times of Roman and other oppressive and tyrannical governments. ${ }^{31}$ Therefore, consistent with the principle in Jewish law respecting the inherent authority of a just legal system, ${ }^{32}$ many have concluded that, under most circumstances, there is no pro-

25. See Meir Tamari, With All Your Possessions: Jewish Ethics and ECONOMIC LifE 159-208 (1987); see also BROYDE, supra note 2, at 115-22.

26. See TAmari, supra note 25, at 183-90; see also Aaron LeVIne, Economics and Jewish Law: Halakhic Perspectives 185-213 (1987).

27. See Biser, supra note 6, at 121-22.

28. See id. at 120-21. But see BROYDE, supra note 2, at 53-66, 115-22.

29. See Biser, supra note 6 , at 121. But see BROYDE, supra note 2, at 121 (concluding that contemporary lawyers generally do not violate the primary substantive prohibition even when facilitating a transaction involving interest).

30. See Talmud Bavli, Baba Metzia 83b-84a. Over the years, codes of Jewish law have often prohibited facilitating the arrest and prosecution of Jewish criminal defendants in a secular legal system. See Biser, supra note 6 , at 125 (citing sources); Michael J. Broyde, Informing on Others for Violating American Law: A Jewish Law View, 43 J. Halacha \& Contemp. Soc'y 5, 5-14 (2002).

31. See Biser, supra note 6, at 126-27.

32. See J. David Bleich, Jewish Law and the State's Authority to Punish Crime, 12 Cardozo L. Rev. 829 (1991); Aaron Kirschenbaum \& Jon Trafimow, The Sovereign Power of the State: A Proposed Theory of Accommodation in Jewish Law, 12 Cardozo L. Rev. 925 (1991); Aaron Rakefet-Rothkoff, Dina D'Malkhuta DinaThe Law of the Land in Halakhic Perspective, 13 Tradition 5 (1972); Hershel 
hibition against assisting the American government in appropriate prosecution of Jewish criminal defendants. ${ }^{33}$

Likewise, attitudes under Jewish law toward the practice of criminal defense may depend on the implications and application of yet another Talmudic passage. The Talmud recounts an episode in which a rabbi was approached by individuals who were rumored to have committed a homicide and were attempting to remain in hiding. ${ }^{34}$ After some deliberation, the rabbi decided neither to assist them in hiding nor to expose them to their pursuers, but instead instructed them to hide by themselves. ${ }^{35}$ Although a number of aspects of both the facts of the case and the rabbi's analysis are open to interpretation, ${ }^{36}$ some commentators understand the rabbi's decision not to assist the apparent fugitives as consistent with the Biblical command to "eradicate evil from your midst." 37 Based on this explanation, some authorities of Jewish law have found that the work of a criminal defense attorney, generally requiring representation of defendants who have, in fact, committed crimes, ${ }^{38}$ would likely violate the command. ${ }^{39}$ Yet again, however, others have suggested that such concerns would not pertain to the American criminal justice system, in which the legal system sanctions-and mandates-the function of the criminal defense attorney, not as a means of subverting justice, but as integral to insure the fairness of the process through which guilty criminals are convicted and punished. ${ }^{40}$

In addition to substantive challenges the practice of law may pose to the observance of various areas of Jewish religious obligation, a number of tactics typically employed by and expected of lawyers likewise seem to conflict with legal and ethical teachings in Jewish tradition. For example, the lawyer's duty to advocate

Schachter, "Dina De'malchusa Dina": Secular Law as a Religious Obligation, $1 \mathrm{~J}$. Halacha \& CONTEMP. SOC'y 103 (1981).

33. See BROYDE, supra note 2, at 83-88; Biser, supra note 6, at 126-27;

Broyde supra note 30 passim; Schachter, supra note 32, at 117-19.

34. See Talmud Bavl, Niddah 61a.

35. See id.

36. See BroYde, supra note 2, at 91-94; Schachter, supra note 32, at $120-21$.

37. Deuteronomy 19:19. See Schachter, supra note 32, at 121.

38. See, e.g., Alan M. Dershowitz, The Best Defense xiv (1982) (stating that "the vast majority of criminal defendants are [factually] guilty of the crimes with which they are charged.").

39. See Biser, supra note 6, at 128; Schachter, supra note 32, at 121-22.

40. See BROYDE, supra note 2, at 94-96. In the words of Lon Fuller, our criminal justice system "aims at keeping sound and wholesome the procedures by which society visits its condemnation on an erring member." Lon L. Fuller, The Adversary System, in TALKS on American Law 35 (Harold J. Berman ed., 1961). 
the position of the client includes advancing arguments that, although not frivolous, may not comport with the lawyer's own factual or legal assessment. ${ }^{41}$ Likewise, commercial and transactional lawyers, among others, may find themselves involved in a difficult bargaining process that calls for tough and unpleasant, if not morally questionable, negotiation tactics. ${ }^{42}$ In the courtroom, lawyers may have to resort to unpleasant and even insulting or embarrassing treatment of opposing witnesses. ${ }^{43}$ Perhaps most significantly, the prevailing basic norm of lawyering requires zealous representation of a client's interests, often understood to include the general absence of any consideration of the consequences to others. ${ }^{44}$

Thus, the practice of law in the American adversary system of justice may entail tactics that involve elements of intellectual dishonesty, decidedly hostile behavior toward others, and a general disregard for the interests of anyone but the client. Such tactics seem not only in potential conflict with substantive aspects of Jewish law, but also, on some level, fundamentally incompatible with basic Jewish ethical tenets and teachings. ${ }^{45}$ Indeed, concerns over the nature of these and other adversarial tactics have motivated efforts among leading American ethics scholars to

41. Indeed, a criminal defense attorney and, according to some, an attorney in a civil case, may-and arguably should-cross-examine a truthful adversarial witness in a manner designed to discredit the witness in the eyes of the jury, and may rely on truthful evidence to persuade the jury of an inference the lawyer knows is false. See Samuel J. Levine, The Yale L. Rosenberg Memorial Lecture: Taking Prosecutorial Ethics Seriously: A Consideration of the Prosecutor's Ethical Obligation to "Seek Justice" in a Comparative Analytical Framework, 41 Hous. L. Rev. 1337, 1344-46 \& nn.19-27 (2004).

42. See, e.g., Geoffrey M. Peters, The Use of Lies in Negotiation, 48 OHIO ST. L.J. 1 (1987); Alvin Rubin, A Causerie on Lawyers' Ethics in Negotiation, 35 LA. L. REv. 577 (1975); Gerald Wetlaufer, The Ethics of Lying in Negotiations, 75 Iowa L. REv. 1219 (1990); see also BroYde, supra note 2, at 123-25; Steven H. Resnicoff, Lying and Lawyering: Contrasting American and Jewish Law, 77 Notre DAME L. Rev. 937 (2002); Thomas L. Shaffer, On Lying for Clients, 71 Notre Dame L. Rev. 195 (1996).

43. See, e.g., GiLlers, supra note 8, at 367-71 (describing the debate over the tactics of Max Steuer's cross-examination of truthful witnesses in the criminal trial connected with the Triangle Shirtwaist Company fire).

44. See Model Code of Prof'l Responsibility Canon 7 (1980) ("A lawyer should represent a client zealously within the bounds of the law."); MoDEL Rules of Prof'l Conduct R. $1.3 \mathrm{cmt}$ (2002) ("A lawyer should act with commitment and dedication to the interests of the client and with zeal in advocacy upon the client's behalf."); see also FrEEdMAN \& SMITH, supra note 8, at 71-127.

45. See Biser, supra note 6, at 129-35; Greisman, supra note 20, at 2420-26; Resnicoff, supra note 20, at 96-104. See also Rabbi Menachem Mendel Blachman, The Sacrifice of Intellectual Honesty, http://www.kby.org/torah/ article.cfm?articleid=1263. 
reassess, rethink, and even reformulate the ethical obligations of American lawyers. ${ }^{46}$

In short, even a brief survey of substantive and tactical aspects of legal practice demonstrates a number of issues of potential conflict between the lawyer's professional obligations and the requirements of Jewish law. As presented here, these issues are intended to illustrate some of the considerations involved in analyzing the American practice of law under Jewish legal tradition. Resolution of these issues requires a thorough and accurate understanding of both Jewish law and the complexities of American law and lawyering on their own terms, coupled with the ability to then determine the relationship between them.

\section{B. Broader Aspects of Legal Practice: Utilization of Resources and Abilities}

Beyond technical aspects, both substantive and tactical, of the practice of law, a consideration of legal practice through a perspective of Jewish tradition might look to the manner in which lawyers utilize their resources and abilities. Drawing upon the example of sanctifying the physical and mundane by providing food for those in need, ${ }^{47}$ in accordance with the imperative of charity ${ }^{48}$ lawyers may find virtue in providing specialized assistance to those for whom it might otherwise remain unavailable,

46. See, e.g., William H. Simon, The Practice of Justice: A Theory of LAWYERS' Ethics (1998); David Luban, The Adversary System Excuse, in THE GoOD Lawyer: LAWyers' Roles and LAWYers' Ethics 83 (David Luban ed., 1983); Heidi Li Feldman, Codes and Virtues: Can Good Lauyers Be Good Ethical Deliberators?, 69 S. CAL. L. REv. 885 (1996); Robert W. Gordon, Corporate Law Practice as a Public Calling, 49 Mo. L. Rev. 255 (1990); Russell G. Pearce, Model Rule 1.0: Lawyers are Morally Accountable, 70 Fordham L. Rev. 1805 (2002); Gerald J. Postema, Moral Responsibility in Professional Ethics, 55 N.Y.U. L. REv. 63 (1980); Murray L. Schwartz, The Professionalism and Accountability of Lawyers, 66 CALIF. L. REv. 669 (1978); Thomas L. Shaffer, The Unique, Novel, and Unsound Adversary Ethic, 41 VAND. L. REv. 697 (1988); Serena Stier, Legal Ethics: The Integrity Thesis, 52 Онго Sт. L. J. 551 (1991); Maura Strassberg, Taking Ethics Seriously: Beyond Positivist Jurisprudence in Legal Ethics, 80 IowA L. Rev. 901 (1995); W. Bradley Wendel, Public Values and Professional Responsibility, 75 Notre Dame L. Rev. 1 (1999); Fred C. Zacharias \& Bruce A. Green, Reconceptualizing Advocacy Ethics, 74 Geo. Wash. L. Rev. 1 (2005); Fred C. Zacharias, Reconciling Professionalism and Client Interest, 36 WM. \& MARY L. Rev. 1303 (1995). See generally Samuel J. Levine, Taking Ethical Discretion Seriously: Ethical Deliberation as Ethical Obligation, 37 IND. L. REv. 21 (2003).

47. See supra note 18 and accompanying text.

48. See, e.g., MaImonides, supra note 5, Laws of Matanoth Ani'im, ch. 10; TAMARI, supra note 25, at 248-62; see also Joseph B. Soloveitchik, YemeI ZichARON 43-45 (1996). 
in the form of pro bono representation. ${ }^{49}$ Moreover, in spite of the aversion toward professional advocacy in the Jewish legal system, ${ }^{50}$ the Biblical verse, "[o]pen your mouth for those who are mute ... open your mouth, judge righteously, and plead the cause of those who are poor and needy," ${ }^{51}$ indicates that Jewish law requires adequate presentation of the claims of parties unable to represent themselves. ${ }^{52}$ Thus, to the extent that Jewish thought would generally approve of the practice of law in the American adversary system of justice ${ }^{53}$ it would seem that protecting the rights of the needy may qualify as a particularly appropriate form of advocacy. ${ }^{54}$

On a broader level, Jewish tradition emphasizes the duty, incumbent upon both individuals and society, to insure justice, with special care for those who are downtrodden and disadvantaged ${ }^{55}$ Indeed, the Jewish nation originated in the figure of Abraham, whose arguments in behalf of the people of Sodom

49. See, e.g., Steven Lubet \& Cathryn Stewart, A “Public Assets" Theory of Lawyers' Pro Bono Obligations, 145 U. PA. L. Rev. 1245 (1997); Deborah L. Rhode, Cultures of Commitment: Pro Bono for Lawyers and Law Students, 67 FordHAM L. REv. 2415 (1999).

50. See supra notes 2-7 and accompanying text.

51. Proverbs 31:8-9. See also Yechiel Hillel Altschuller, Metzudath Dovid (commenting on Proverbs 31:8-9).

52. See Joseph Karo, Kesef Mishne (commenting on Maimonides, supra note 5, Laws of Sanhedrin 21:11); Joseph Karo, Shulchan Aruch Choshen Mishpat 17:9; MAImONides, supra note 5, Laws of Sanhedrin 21:11; see also TALMUD Yerushalmi, Sanhedrin 3:8, cited in Herring, supra note 5, at 96; Brovde, supra note 2, at 13, 21-22; Herring, supra note 5, at 102-06; RABBi Shlomo BEN Adret, Teshuvoth ha-Rashba 2:393, cited in Broyde, supra note 2, at 21.

53. See supra Part II.A.

54. See Deborah L. Rhode, Access to Justice (2004); 2004 Symposium Transcript: Access to Justice: Does it Exist in Civil Cases?, 17 Geo. J. Legal ETHics 455 (2004); Conference on the Delivery of Legal Services to Low-Income Persons: Professional and Ethical Issues, 67 Fordham L. Rev. 1713 (1999); Colloquium, Deborah L. Rhode's Access to Justice, 73 Fordham L. Rev. 841 (2004); Deborah L. Rhode, Access to Justice, 69 Fordham L. Rev. 1785 (2001); Deborah L. Rhode, Access to Justice: Connecting Principles to Practice, 17 Geo. J. Legal Ethics 369 (2004).

55. See SolovertchiK, supra note 10 , at 91 (describing the attributes of the leader who "takes up [a] stand in the midst of the concrete world, [with] feet planted firmly on the ground of reality, and [ ] looks about and sees, listens and hears, and publicly protests against the oppression of the helpless, the defrauding of the poor, and the plight of the orphan"); see also id. (quoting the renowned scholar and communal leader, Rabbi Chaim of Brisk, stating that the "function of a rabbi" is primarily "[ $t]$ o redress the grievances of those who are abandoned and alone, to protect the dignity of the poor, and to save the oppressed from the hands of [the] oppressor," more so than to provide "ritual decisions" or "political leadership"); TAMARI, supra note 25, at 242-77. 
and Gomorrah stand as a model of advocacy for justice. ${ }^{56}$ Likewise, the imperative of striving to achieve social justice and fairness, with an eye toward mercy and compassion for those in society who are less fortunate, continues throughout sources of Jewish law and ethics, in the form of legal precepts, dramatic narrative, and hortatory exhortation. ${ }^{57}$ Thus, it is not uncommon for American lawyers working for social justice to see themselves as following the powerful teachings, if not the religious traditions, of the Biblical prophets. ${ }^{58}$ In fact, these traditions might suggest that, in light of the measure of power and influence lawyers often attain in both public and private arenas, the practice of law carries a corresponding obligation of counseling disenfranchised clients ${ }^{59}$ and working to protect their rights and interests. ${ }^{60}$

56. See Genesis 18:20-33; see also Rabbi Nafatali Tzvi Berlin, Ha'emek Davar, Introduction to Commentary on Genesis (Yeshivat Volojine ed. 1999); 2 Eliyahu Dessler, Michtav M'Eliyahu 181-82 (Aryeh Carmell \& Chaim Friedlander eds., 1963).

57. See, e.g., Samuel J. Levine, Halacha and Aggada: Translating Robert Cover's Nomos and Narrative, 1998 UTAH L. Rev. 465, 497-98 (quoting Psalms 68:5-6; MAImonides, Code Of LAW, at Laws of Estates 11:12); see also TAMARI, supra note 25 , at $242-77$.

58. See Jerold S. Auerbach, Rabbis and Lawyers: The Journey from Torah to Constitution passim (1990); Thomas L. Shaffer, The Biblical Prophets as Lawyers for the Poor, 31 Fordham URB. L.J. 15 (2003); Thomas L. Shaffer, Lawyers and the Biblical Prophets, 17 Notre Dame J.L. Ethics \& Pub. Pol'y 521 (2003); Thomas L. Shaffer, Lawyers as Prophets, 15 St. Thomas L. Rev. 469 (2003); see also Ronald R. Garet, Judges as Prophets: A Coverian Interpretation, 72 S. CAL. L. Rev. 385 (1999).

59. See, e.g., Freedman \& Smith, supra note 8, at 6-9, 49-55; Thomas L. Shaffer \& Robert F. Cochran, Jr., Lawyers, Clients, and Moral ResponsibilITY (1994); Wolfram, supra note 8, at 76-78; Edward Dauer \& Arthur Leff, Correspondence, The Lawyer as Friend, 86 YALE L.J. 573 (1977); Charles Fried, The Lawyer as Friend: The Moral Foundations of the Lawyer-Client Relation, 85 YAlE L.J. 1060 (1976).

60. For perspectives of contemporary American legal ethics scholars applying many of these concepts to the work of Jewish lawyers advocating social justice, see, e.g., Monroe H. Freedman, Legal Ethics from a Jewish Perspective, 27 Tex. Tech L. Rev. 1131 (1996); Sanford Levinson, Identifying the Jewish Lawyer: Reflections on the Construction of Professional Identity, 14 Cardozo L. Rev. 1577, 1578-79 (1993); Russell G. Pearce, Jewish Lawyering in a Multicultural Society: A Midrash on Levinson, 14 CARdozo L. REv. 1613, 1635-36 (1993); Russell G. Pearce, The Jewish Lawyer's Question, 27 Tex. Tech L. Rev. 1259 (1996); Nancy B. Rapoport, Living "Top-Down" in a "Bottom-Up" World: Musings on the Relationship Between Jewish Ethics and Legal Ethics, 78 NEB. L. Rev. 18 (1999); Abbe Smith \& William Montross, The Calling of Criminal Defense, 50 Mercer L. Rev. 443, 451 (1999); see also Levine, Broad Life, supra note 9; Levine, Practice of Law as a Religious Calling, supra note 9.

For a thoughtful recent contribution to this literature, see Amy Porter, Representing the Reprehensible and Identity Conflicts in Legal Representation, 14 TEMP. 


\section{Conduct Incidental the Practice of Law}

Finally, Jewish tradition addresses more generally the manner in which individuals conduct themselves in all of their daily activities. Thus, for example, in addition to observance of dietary laws and sharing food with those in need, the mundane act of taking part in a meal can be transformed into a noble pursuit in which participants infuse their meal with spiritual study, thus eating at the "table of God." 61 Likewise, building on the Biblical verse that commands "in all of your ways acknowledge [God]," 62 Jewish thought has emphasized that all of life's endeavors, viewed and undertaken in proper perspective, have the potential to be performed in a way that constitutes serving God. ${ }^{63}$

Among various occupations, the practice of law may present some of the most formidable challenges to and, conversely, some of the most promising opportunities for acknowledging God in all of one's ways. ${ }^{64}$ Legal practice increasingly demands a disproportionate degree of the lawyer's time and energy, dominating both the intellect and the emotions amidst an often pressured and combative atmosphere. Under such circumstances, the lawyer may find it difficult to maintain an appropriate level of respectful behavior toward others, including clients, co-workers, and professional adversaries. Of course, by nature, legal representation and advocacy usually require a degree of argumentation and confrontation. ${ }^{65}$ Nevertheless, to the extent that common courtesies and basic morals sometimes seem trivial in

Pol. \& Civ. Rts. L. Rev. 143 (2004). Cf. Thomas L. Shaffer, On Being a Chris TIAN AND A LAWYER 35-104 (1981); Conference, Lawyers, Religious Faith, and Social Justice: Our Responsibility to "the Orphan, the Widow, the Alien" and "the Least of These," Pepperdine University School of Law (Feb. 4-5, 2005); Thomas L. Shaffer, Should a Christian Lawyer Serve the Guilty?, 23 GA. L. REv. 1021 (1989).

61. Talmud, Avoth 3:3.

62. Proverbs 3:6.

63. See Levine, Practice of Law as a Religious Calling, supra note 9, at 412-13 \& nn.3-6 (citing sources).

64. For more general applications of the principle of serving God through proper conduct in the workplace, see RabBI Reuven ZiEgler, By His Light: Character and Values in the Service of God, Based on Addresses by RabBi Aharon Lichtenstein 1-74 (2003); Yitzchok A. Breitowitz, The Spiritual Challenges of the Workplace, 62 Jewish ACTION 18 (2002); David Hojda, Personal and Financial Integrity and Halachah, 66 JEwISH Action 32 (2005) (reviewing several recently published books relevant to these issues); Levine, Practice of Law as a Religious Calling, supra note 9, at 414-15 \& nn.11-20 (citing sources); see also Howard Gardner et al., Good Work: When Excellence and Ethics Meet (2001).

65. For different views on the appropriate degree of confrontational behavior in practicing law, compare, e.g., Final Report of the Committee on Civility of the Seventh Federal Judicial Circuit, 143 F.R.D. 441 (1992), with Amy R. Mash- 
such an atmosphere, ${ }^{66}$ Jewish law and ethics may provide lawyers a particularly valuable perspective, serving as a reminder of the imperative to serve God and morality in all of life's activities.

\section{CONCLUSION}

As Rabbi Soloveitchik has eloquently explained, Jewish thought "does not differentiate between the [person] who stands in [the] house of worship, engaged in ritual activities, and the mortal who must wage the arduous battle of life." ${ }^{67}$ Jewish tradition "rejects such a personality split, such a spiritual schizophrenia[,]"68 instead "declar[ing] that [a person] stands before God not only in the synagogue but also in the public domain, in [one's] house, while on a journey, while lying down and rising up." 69 In short, "[t]he marketplace, the street, the factory, the house, the meeting place, the banquet hall, all constitute the backdrop for the religious life." 70 Thus, Jewish law and ethics address and provide a conceptual framework for spiritual enrich-

burn, Professionalism as Class Ideology: Civility Codes and Bar Hierarchy, 28 VAL. U. L. Rev. 657 (1994); see also FreEdmAN \& SMITH, supra note 8, at 123-27.

66. See, e.g., Robert S. Caine, Letter, A Lawyer's View of Being a Litigant, N.Y.L.J., May 16, 1994, at 2, cited in GILlERS, supra note 8, at 68:

As a litigant, you're often subjected to indignities and lack of consideration by lawyers and judges.

There's something wrong with us lawyers-and judges, toowhen we can't realize the harm we're doing to our clients and to the public, the heartache and frustration and pain we cause to others because we fail to attend civilly and promptly to the needs of others for communication.

Id.; see also Steven G. Gey, A Tribute to Steve Goldstein: Introduction: It Just Isn't Fair, 22 Fla. ST. U. L. REv. 799, 800 (1995) ("We lawyers are many fine things, but we are usually not very good at impersonating human beings. We are often a cold and competitive lot, and our time is far too precious to squander it on the common decencies of ordinary human interaction."); Thomas L. Shaffer, Tow ering Figures, Enigmas, and Responsive Communities in American Legal Ethics, 51 ME. L. Rev. 229, 239 (1999) (advising graduating law students "not to forget the morals they brought to law school, not to let law professors dissuade them from what they had learned from their mothers and their towns, from their religious formation and from their friends and teachers in college"). For a similar critique of doctors, see Barron H. Lerner, Practicing Medicine Without a Swagger, N.Y. Times, Aug. 23, 2005, at F6 (describing "some physicians [who] became vain and arrogant, making extraordinary demands and openly misbehaving," including "certain surgeons who ran operating rooms like fiefs, screaming at staff members and even throwing surgical instruments to signify their discontent").

67. Solovertchik, supra note 10 , at 93 .

68. Id.

69. Id.

70. Id. at 94 . 
ment in all facets of human behavior, from overtly religious settings to the workplace to leisurely activities. ${ }^{71}$ In some ways, therefore, from a perspective of Jewish tradition, American practice of law constitutes but another area of activity, to be analyzed and sanctified in accordance with its intrinsic challenges to and opportunities for religious observance and spirituality.

Notably, in recent years there has developed a wide perception of crisis in the work of lawyers, ${ }^{72}$ representative of the kind

71. Indeed, the imperative to behave properly applies as much on a basketball court as in a court of law. Thus, consistent with the three-tiered conceptual framework that illustrates different ways legal practice may accord with Jewish law and ethics, various aspects of engaging in sports may provide both challenges to and opportunities for serving God. For example, on a technical level, in adherence to Jewish religious observance, an individual may not participate in sports activities on the Sabbath or a Holy Day. See, e.g., Ira Berkow, When Basketball is a Matter of Faith: A Budding Star Balances His Game and His Religion, N.Y. TImes, Aug. 25, 2000, at D1 (describing student who accepted offer to play on basketball team at a Division I college, emphasizing that he would not play on the Sabbath); Murray Chass, On Yom Kippur, Green Opts to Miss at Least One Game, N.Y. Times, Sept. 23, 2004 (describing baseball player Shawn Green's decision not to play on Yom Kippur during the 1994 pennant race); Levinson, supra note 60, at 1579-81 (describing Sandy Koufax's decision not to pitch on Yom Kippur, including the first game of the 1965 World Series, and Hank Greenberg's decision not to play on Yom Kippur during the 1934 pennant race); Alan Schwarz, In the Spirit of Koufax, N.Y. Times, Sept. 9, 2001 (describing Shawn Green's decision not to play on Yom Kippur during the 1991 pennant race).

On a broader level, athletes might dedicate some of the money and fame they have earned for the benefit of noble causes such as assisting those in need.

Finally, perhaps most instructive for a consideration of the practice of law, athletes may demonstrate moral character in the way they conduct themselves in the midst of competitive play. See Berkow, supra, at D4 (quoting student's observation that "Torah and basketball go hand in hand for me. Torah makes me a better basketball player because it emphasizes good character, integrity and responsibility. You have to be on time, respect others and work hard."); ZIEGLER, supra note 64 , at $42-43$ :

[T] he world of sports is, in a certain sense, trivial; mature adults are running around trying to put a ball through a hole. Nevertheless, moral qualities can and do come into play: cooperation, team [ ] play, an attempt to get the maximum out of yourself, etc. The inherent effort of the person . . . or the loneliness of the long-distance runner in ... isolation, are very significant moral elements. . . [T] here is no question that within the essentially trivial world of sports, real moral greatness and real moral degradation can be seen. If you see someone on the basketball court who wants only to shoot and score, and defense means nothing to [the player], this is not simply disturbing to another basketball player, but is morally repugnant.

72. See Mary Ann Glendon, A Nation Under Lawyers: How the Crisis in the Legal Profession is Transforming American Society (1994); ANTHony T. Kronman, The lost Lawyer: Failing ideals of the Legal Profession (1993); Sol M. Linowitz with Martin Mayer, The Betrayed Profession: Lawy- 
of "deep fissure in one's psychic identity" described by Rabbi Soloveitchik. ${ }^{73}$ Numerous theories have been offered to identify both causes and symptoms of dispirit and discontent among lawyers, ${ }^{74}$ followed by the establishment of various movements and proposals in response. ${ }^{75}$ One of the most promising responses has resulted in the emergence of a religious lawyering movement, ${ }^{76}$ dedicated to examining and demonstrating the relevance of religious values to the practice of law. ${ }^{77}$ Ultimately, then, from a perspective of American legal practice, Jewish legal and ethical teachings present a model for a consideration of the way religious traditions and other value systems may inform and help improve exploration of and attitudes toward the work and ethics of lawyers. ${ }^{78}$

ering at the End of the Twentieth Century (1994); see also sources cited supra note 12.

73. Solovertchiк, supra note 10, at 93; see also Samuel J. Levine, Introductory Note: Symposium on Lawyering and Personal Values: Responding to the Problems of Ethical Schizophrenia, 38 CATH. Law. 145 (1998); Thomas L. Shaffer, On Living One Way in Town and Another Way at Home, 31 VAL. U. L. REv. 879 (1997).

74. See supra note 72.

75. See, e.g., Freedman \& Smith, supra note 8, at 122-27; Gillers, supra note 8, at 9-13; Rob Atkinson, A Dissenter's Commentary on the Professionalism Crusade, 74 Tex. L. Rev. 259 (1995); Levine, Faith in Legal Professionalism, supra note 12; Pearce, The Professional Paradigm Shift, supra note 12.

76. See, e.g., Howard Lesnick, Riding the Second Wave of the So-Called Religious Lawyering Movement, 75 ST. John's L. REv. 283 (2001); Russell G. Pearce, Foreword: The Religious Lawyering Movement: An Emerging Force in Legal Ethics and Professionalism, 66 Fordham L. Rev. 1075 (1998); Russell G. Pearce \& Amelia J. Uelmen, William A. Brahms Lecture on Law and Religion: Religious Lawyering in a Liberal Democracy: A Challenge and an Invitation, 55 CASE W. REs. L. REv. 127 (2004); Robert K. Vischer, Heretics in the Temple of Law: The Promise and Peril of the Religious Lauyering Movement, 19 J. L. \& Relicion 427 (2003-04).

77. See, e.g., Robert F. Cochran, Jr., Introduction: Can the Ordinary Practice of Law be a Religious Calling?, 32 Pepp. L. Rev. 373 (2005); Rose Kent, What's Faith Got to Do With It? 6 Fordham Law. 11 (Summer 2001) (describing Fordham University School of Law's Institute on Religion, Law \& Lawyer's Work); Symposium, Faith and the Law, 27 Tex. Tech L. Rev. 925 (1996); Symposium, Lawyering and Personal Values, 38 CATH. LAw. 145 (1998); Symposium, Rediscovering the Role of Religion in the Lives of Lawyers and Those They Represent, 26 FORDHAM URB. L.J. 821 (1999); Symposium, The Relevance of Religion to a Lawyer's Work: An Interfaith Conference, 66 Fordham L. Rev. 1075 (1998); see also The Institute on Law, Religion, and Ethics, http://law.pepperdine.edu/ilre/ (last visited Mar. 28, 2006).

78. Cf. GARDNER ET AL., supra note 64 , at 248 :

You-like the rest of us-will find it very difficult to stay on course unless you feel loyal to an enduring tradition. Sometimes your loyalty or trust may be based on religious faith .... Without strong foundations in traditions that give meaning to the future, it is hard to keep up professional values under the pressure of countervailing forces. And so, as often as needed, unclutter your mind: Revisit those codes, docu- 
ments, and exemplars that are integral to your domain-whether they are as ancient as the words of Moses, Hammurabi, or Hippocrates, or as recent as the mission statement of your favorite organization. 
HeinOnline -- 20 Notre Dame J.L. Ethics \& Pub. Pol'y 282006 